\title{
SENAM KAKI DIABETES PADA PENDERITA DIABETES MELLITUS (STUDI LITERATUR)
}

\author{
Yora Nopriani $^{1}$, Silvia Ramadhani Saputri ${ }^{2}$ \\ Prodi S1 Keperawatan STIKES Mitra Adiguna \\ Jl. Kenten Permai Blok J No 9-12 Bukit Sangkal Palembang \\ Email : yoranopriani90@gmail.com
}

\begin{abstract}
Abstrak
World Health Organization (WHO, 2020) memperkirakan sekitar 422 juta orang di seluruh dunia menderita diabetes. Senam kaki adalah kegiatan atau latihan yang dilakukan oleh pasien diabetes melitus untuk mencegah terjadinya luka dan membantu melancarkan peredaran darah bagian kaki. Tujuan penelitian ini adalah untuk menganalisis hasil jurnal mengenai senam kaki diabetes pada penderita diabetes melitus (studi literatur). Metode penelitian menggunakan metode studi kepustakaan atau literatur review. Jenis literatur review yang diguanakan dalam penelitian menggunakan metode meringkas (summarize). Berdasarkan hasil lilteratur review terhadap 15 literatur diketahui bahwa latihan senam kaki diabetes akan menyebabkan terjadinya peningkatan aliran darah, maka akan lebih banyak jala-jala kapiler terbuka sehingga lebih banyak tersedia reseptor insulin dan reseptor menjadi lebih aktif yang akan berpengaruh terhadap penurunan glukosa darah pada pasien diabetes. Latihan jasmani dapat menurunkan kadar glukosa darah karena latihan jasmani akan meningkatkan pemakaian glukosa oleh otot yang aktif. Salah satu dari latihan jasmani adalah senam kaki. Saran diharapkan hasil penelitian ini sebagai acuan bagi peneliti sendiri dan peneliti selanjutnya agar dapat melanjutkan penelitian berikutnya dengan metode yang berbeda tentang penanganan diabetes mellitus sehingga dapat lebih bervariasi.
\end{abstract}

\section{Kata Kunci ： Senam Kaki, Diabetes}

\begin{abstract}
Abstrack
The World Health Organization (WHO, 2020) estimates that around 422 million people worldwide suffer from diabetes. Foot gymnastics is an activity or exercise carried out by patients with diabetes mellitus to prevent injuries and help improve blood circulation in the legs. The purpose of this study was to analyze the results of journals regarding diabetic foot exercises in people with diabetes mellitus (literature study). The research method uses a literature study or literature review method. The type of literature review used in this study uses the method of summarizing. Based on the results of a literature review of 15 literatures, it is known that diabetic foot exercises will cause an increase in blood flow, so that more capillary nets will open so that more insulin receptors are available and receptors become more active which will affect the decrease in blood glucose in diabetic patients. . Physical exercise can reduce blood glucose levels because physical exercise will increase the use of glucose by active muscles. One of the physical exercises is leg gymnastics. It is hoped that the results of this study will serve as a reference for the researchers themselves and future researchers in order to continue further research with different methods of handling diabetes mellitus so that it can be more varied.
\end{abstract}

Keywords $\quad$ : Foot Exercise, Diabetes

Jurnal Kesehatan dan Pembangunan, Vol. 11, No. 22, Juli 2021 


\section{PENDAHULUAN}

Diabetes Mellitus (DM) merupakan salah satu penyakit yang berbahaya yang kerap disebut sebagai silent killer selain penyakit jantung, yang merupakan salah satu masalah kesehatan yang besar. Diabetes Mellitus (DM) dari bahasa yunani: diabainein, tembus atau pancuran air, sedangkan Mellitus dalam bahasa latin: rasa manis yang juga dikenal di indonesia dengan istilah penyakit kencing gula atau kencing manis yaitu kelainan metabolis yang disebabkan oleh banyak faktor dengan simtoma berupa hiperglikemia kronis dan gangguan metabolisme karbohidrat, lemak dan protein. Komplikasi jangka lama termasuk penyakit kardiovaskular, kegagalan kronis ginjal, kerusakan retina yang dapat menyebabkan kebutaan, serta kerusakan saraf yang dapat menyebabkan impotensi dan gangren dengan resiko amputasi (Lariwu, 2017).

World Health Organization (WHO, 2020) memperkirakan sekitar 422 juta orang di seluruh dunia menderita diabetes, sebagian besar tinggal di negara berpenghasilan rendah dan menengah, dan 1,6 juta kematian secara langsung dikaitkan dengan diabetes setiap tahun. Baik jumlah kasus maupun prevalensi diabetes terus meningkat selama beberapa dekade terakhir (WHO, 2020)

International Diabetes Federation (IDF) mencatat saat ini setiap 8 detik ada orang yang meninggal akibat diabetes di dunia. Jumlah diabetesi di dunia mencapai 415 juta jiwa meningkat menjadi 425 juta jiwa pada tahun 2017, namun banyak orang yang tidak sadar dirinya atau anggota keluarganya terkena diabetes. Lima provinsi dengan prevalensi diabetes tertinggi adalah DKI Jakarta, DI Yogyakarta, Kalimantan Timur, Sulawesi Utara, dan Jawa Timur. Penduduk di wilayah tersebut perlu memperhatikan pola konsumsi atau menjaga aktivitas supaya tidak diabetes (Triwibowo, 2019).

Berdasarkan data Kementrian

Kesehatan Republik Indonesia (Kemenkes RI), hasil Riskesdas 2018 prevalensi DM semua umur di Indonesia pada Riskesdas 2018 yaitu sebesar $1,5 \%$. Sedangkan provinsi dengan prevalensi DM tertinggi semua umur berdasarkan diagnosis dokter juga masih di DKI Jakarta sebesar 3,4\% dan terendah di NTT sebesar $0,8 \%$. Sedangkan untuk Provinsi Sumatera Selatan jumlah penderita Diabetes Mellitus berdasarkan diagnosis dokter sebesar 1,4\% (Kemenkes, 2018).

Pengelolaan DM dapat dilakukan dengan terapi farmakologis dan terapi non farmakologis. Pengelolaan terapi farmakologis yaitu pemberian insulin dan obat hipoglikemik oral. Sedangkan non farmakologis meliputi pengendalian berat badan, latihan olahraga, dan diet. Latihan jasmani merupakan salah satu dari empat pilar utama penatalaksanaan diabetes mellitus. Latihan jasmani dapat menurunkan kadar glukosa darah karena latihan jasmani akan meningkatkan pemakaian glukosa oleh otot yang aktif (Wibisana, 2017).

Olahraga akan meningkatkan pemakaian glukosa oleh otot yang aktif, dimana otot mengubah simpanan glukosa menjadi energi sehingga secara langsung dapat menyebabkan penurunan glukosa dalam darah. Selain itu, pada saat berolahraga atau melakukan latihan fisik terjadi pembakaran kalori yang menambah metabolisme tubuh, sehingga selain dapat mengendalikan kadar gula darah juga dapat menurunkan berat badan. Olahraga akan mengurangi jumlah kolesterol LDL, meningkatkan HDL, dan mengurangi trigliserida dalam darah, yang berarti yang berarati mengurangi risiko komplikasi penyakit jantung kardiovaskuler. Dengan demikian olahraga bukan hanya akan memberikan perbaikan dalam diabetes melitus, namun juga dapat mengurangi risiko terjadinya komplikasi (Hardika, 2018).

Salah satu dari latihan jasmani adalah senam kaki. Senam kaki adalah kegiatan atau latihan yang dilakukan oleh pasien diabetes melitus untuk mencegah terjadinya luka dan membantu melancarkan peredaran darah bagian kaki. Senam kaki ini bertujuan untuk memperbaiki sirkulasi darah sehingga nutrisi ke jaringan lebih lancar, memperkuat otot-otot kecil, otot betis, dan otot paha, serta mengatasi keterbatasan gerak sendi yang sering dialami oleh pasien Diabetes Melitus (Wibisana, 2017). Berdasarkan hasil penelitian Endriyanto (2016), yang berjudul Efektivitas Senam Kaki Diabetes Melitus Dengan Koran Terhadap Tingkat Sensitivitas Kaki Pada Pasien DM Tipe 2 Di Instalasi Rawat Inap 
RSUD Arifin Achmad Pekanbaru. Hasil penelitian ini menunjukkan adanya peningkatan sensitivitas kaki yang signifikan pada kelompok eksperimen setelah diberikan perlakuan dengan hasil uji statistik $p<0.05$. Dapat disimpulkan bahwa melakukan senam kaki diabetes melitus dengan koran dapat meningkatkan sensitivitas kaki pada pasien DM tipe 2.

Penderita DM sering mengalami keluhan nyeri pada kaki. Nyeri pada kaki diabetes mellitus dapat di sebabkan adanya gangguan pembuluh darah, ganguan persyarafan dan adanya infeksi. Keadaan hiperglikemia yang terus menerus, infeksi akan mempunyai dampak pada kemampuan pembuluh darah tidak berkontraksi dan relaksasi berkurang. Hal ini mengakibatkan sirkulasi darah tubuh menurun, terutama kaki, maka akan timbul gejala nyeri pada tungkai bila berdiri, berjalan dan melakukan kegiatan fisik. Pasien DM yang dirawat di Rumah Sakit jarang di ajarkan perlakuan senam kaki Diabetik.

Dari data di atas maka peneliti mengunakan studi pustaka untuk mengetahui literatur review pengaruh senam kaki diabetes terhadap tingkat sensitivitas kaki dan kadar glukosa darah pada penderita diabetes melitus. Studi pustaka adalah suatu studi yang tujuannya untuk memperoleh dukungan teoritis terhadap masalah penelitian yang di pilih, maka peneliti perlu banyak membaca buku, baik berupa buku teks (teori) maupun hasil penelitian orang lain, majalah,jurnal, dan sebagainya (Notoatmojo, 2018)

Dalam melakukan studi kasus ada beberapa teknik yang di gunakan antara lain, mengupas atau mengkritik (criticize), membandingkan( compare), Meringkas (summarize), mengumpulkan (synthesize), dan bertentangan (Contrast). Dan penulis mengunakan metode summarize, yaitu Senam Kaki Diabetes Pada Penderita Diabetes Melitus (Studi Literatur).

\section{METODE PENELITIAN \\ Format Penelitian}

Penelititan ini merupakan penelitian dengan menggunakan metode studi kepustakaan atau literatur review. Dalam penelitian ini penulis mengunakan metode meringkas (summarize).

\section{Pengumpulan Data}

Data yang digunakan dalam penelitian ini berasal dari hasil-hasil penelitian yang sudah dilakukan dan diterbitkan dalam jurnal online nasional dan internasional menggunakan seach engine Google Schoolar dengan kata kunci: senam kaki diabetes, penderita diabetes melitus, diabetes foat gymnestics.

\section{Metode Analisis Data}

Jurnal penelitian yang sesuai dengan kriteria inklusi kemudian dikumpulkan dan dibuat ringkasan jurnal meliputi nama peneliti, tahun terbit jurnal, tujuan penelitian, dan ringkasan hasil atau temuan. Ringkasan jurnal tersebut kemudian dilakukan analisis terhadap isi yang terdapat dalam tujuan penelitian dan hasil/temuan penelitian

\section{HASIL PENELITIAN DAN PEMBAHASAN}

\section{Hasil Penelurusan Jurnal}

Berdasarkan hasil penelusuran di Google Schoolar dengan kata kunci senam kaki diabetes, penderita diabetes mellitus, peneliti menemukan 3.260 judul artikel yang sesuai dengan kata kunci. Artikel yang ditemukan sesuai dengan kata kunci tersebut belum semuanya memiliki tema yang sesuai dengan tujuan penelitian dan terdapat artikel yang duplikasi. Peneliti kemudian melakukan penelusuran menggunakan penelusuran lanjutan Google Schoolar dengan mencari kata kunci dalam judul (in title) yang sesuai kata kunci yang sama dan didapat sebanyak 1.150 jurnal. Artikel penelitian yang memiliki kemiripan tema / isi penelitian kemudian dipilih berdasarkan kriteria yang paling layak dan sesuai dengan tujuan penelitian. Jurnal penelitian yang tidak terpilih, terdapat kemiripan, dan tidak sesuai dengan kriteria inklusi kemudian dilakukan eksklusi yaitu sebanyak 2.110 .

Sebanyak 1.150 artikel yang ditemukan tersebut kemudian dilakukan skrining untuk melihat apakah artikel tersebut memiliki naskah lengkap atau tidak, selanjutnya 830 artikel 
kemudian dieksklusi karena tidak tersedia artikel full text sehingga didapatkan artikel full text. Asasemen kelayakan dilakukan terhadap 320 artikel full text. Artikel penelitian yang memiliki kemiripan tema / isi penelitian kemudian dipilih berdasarkan kriteria yang paling layak dan sesuai dengan tujuan penelitian. Jurnal penelitian yang tidak terpilih, terdapat kemiripan, dan tidak sesuai dengan kriteria inklusi kemudian dilakukan eksklusi sebanyak 310 artikel, sehingga didapatkan 10 artikel full text yang dilakukan review. Alur pemilihan jurnal yang direview dapat dilihat pada gambar 4.1. tentang diagram alur review jurnal.

\section{Pembahasan}

Literatur Review Pengaruh Senam Kaki Diabetes Terhadap Penurunan Kadar Gula Darah Pada Pasien Diabetes Mellitus Tipe II

Dari hasil literatur review yang peneliti lakukan terhadap beberapa literatur jurnal diketahui bahwa karakteristik responden yang mengalami diabetes mellitus tipe II dilihat dari umur sebagian besar berumur > 50 tahun, sebagian besar berjenis kelamin perempuan, kurang beraktivitas.

Hal ini sesuai dengan literatur buku Bustan (2018), yang menyatakan kelompok risiko tinggi (high risk group) DM antara lain:

Usia lebih dari 45 tahun, berat badan lebih (BBR > 110\% atau IMT > $25 \mathrm{~kg} / \mathrm{m}$ ), hipertensi $(>140 / 90 \mathrm{mmHg})$, Ibu dengan riwayat melahirkan bayi > 4000 gram, pernah diabetes sewaktu hamil, riwayat keturunan DM, Kolesterol HDL < $35 \mathrm{mg} / \mathrm{dl}$ atau trigliserida > $250 \mathrm{mg} / \mathrm{dl}$, kurang aktivitas fisik

Dari hasil literatur review yang peneliti lakukan terhadap beberapa literatur jurnal diketahui bahwa dalam hal penanganan diabetes mellitus dapat dilakukan dengan non medis (menggunakan terapi, latihan fisik, dan pengobatan herbal). Dalam penelitian ini peneliti lebih memfokuskan pengobatan non medis dengan melakukan terapi latihan fisik berupa senam kaki diabetes mellitus.

Hal ini sesuai dengan literatur yang didapat menurut Bustan (2018), secara umum pengendalian DM dimaksudkan untuk mengurangi gejala, membentuk berat badan ideal. Dengan demikian, prinsip dasar manajemen pengendalian atau penanganan DM meliputi:

a. Pengaturan makanan : yang pertama dan kunci manajemen DM yang sekilas tampaknya mudah tapi kenyataannya sulit mengendalikan diri terhadap nafsu makan.

b. Latihan jasmani (senam kaki diabetes)

c. Perubahan perilaku risiko

d. Obat anti diabetik

e. Intervensi bedah : sebagai pilihan terakhir, kalau memungkinkan dengan cangkok pankreas.

Berdarkan literatur review yang peneliti lakukan terhadap beberapa literatur seperti buku, jurnal dan skripsi yang berhubungan dengan pengaruh senam kaki diabetes terhadap penurunan kadar gula darah pada pasien diabetes mellitus tipe II didapatkan bahwa senam kaki diabetes berpengaruh dalam menurunkan kadar gula darah pada pasien diabetes mellitus tipe II.

Dalam jurnal Lariwu (2017) tentang Pengaruh Senam Kaki Diabetes Terhadap Penurunan Kadar Gula Darah Pada Pasien Diabetes Mellitus Tipe II di Klinik Husada Manado. Jenis penelitian ini menggunakan one group pretest-postest. Subjek penelitian ini adalah penderita diabetes mellitus, dengan rentang usia pada umur $<50$ tahun sebanyak $(45,5 \%)$, sedangkan $\geq 50$ tahun sebanyak $(50,5 \%)$, sedangkan durasi latihan dilakukan 2 kali seminggu. Hasil penelitian menunjukkan nilai mean sebelum dilakukan intervensi yaitu 176.15 dan nilai mean sesudah dilakukan intervensi yaitu 118.70 , jadi perbedaan nilai mean sebelum dan sesudah dilakukan intervensi yaitu 57.450 dan nilai $\mathrm{P}$ Value yaitu $0.000<0.05$, jadi Ho di tolak karna ada pengaruh senam kaki diabetes terhadap penurunan kadar gula darah pada pasien diabetes mellitus tipe II di klinik Husada Manado.

Dalam penelitian Lariwu (2017) dijelaskan bahwa komponen latihan jasmani atau olahraga sangat penting dalam penatalaksanaan diabetes karena efeknya dapat menurunkan kadar glukosa darah dengan meningkatkan pengambilan glukosa oleh otot dan memperbaiki pemakaian insulin. Latihan jasmani akan menyebabkan terjadinya peningkatan aliran darah, maka akan lebih banyak jala-jala kapiler terbuka sehingga lebih 
banyak tersedia reseptor insulin dan reseptor menjadi lebih aktif yang akan berpengaruh terhadap penurunan glukosa darah pada pasien diabetes. Keadaan normal setelah makan, kadar glukosa darah meningkat yang akan diikuti kenaikan insulin secara cepat dan menurun setelah nutien yang masuk disimpan. Insulin hormon yang dihasilkan oleh pankreas dibutuhkan untuk memasukkan glukosa dari darah kedalam sel.

Dalam jurnal Wibisana (2017) tentang Pengaruh senam kaki terhadap kadar gula darah pasien diabetes mellitus di RSU Serang Provinsi Banten. Jenis penelitian ini menggunakan one group pretest-postest. Subjek penelitian ini adalah penderita diabetes mellitus, dengan rentang usia pada umur $<50$ tahun sebanyak (13,3\%), 50-59 tahun sebanyak $(33,3 \%)$, dan lebih dari 60 tahun $(6,7 \%)$, durasi latihan dilakukan 2 sekali seminggu. Hasil penelitian didapat diperoleh hasil adanya perbedaan rata-rata kadar gula darah sebelum dan setelah dilakukan senam kaki $(\mathrm{p}=0.001$; $\mathrm{a}=0.05)$. Tidak hanya itu, faktor usia $(\mathrm{p}=0.001$; $\mathrm{a}=0.05)$, intensitas melakukan senam $(\mathrm{p}=0.002$; $\mathrm{a}=0.05)$, konsumsi obat $(\mathrm{p}=0.000 ; \mathrm{a}=0.05)$ sebagai confounding variabel dilihat pengaruhnya terhadap perubahan kadar gula darah setelah dilakukan senam kaki.

Dalam penelitian Wibisana (2017) dijelaskan bahwa pengelolaan DM dapat dilakukan dengan terapi terapi non farmakologis. Terapi non farmakologis meliputi, latihan olahraga. Latihan jasmani merupakan utama penatalaksanaan diabetes mellitus. Latihan jasmani dapat menurunkan kadar glukosa darah karena latihan jasmani akan meningkatkan pemakaian glukosa oleh otot yang aktif. Salah satu dari latihan jasmani adalah senam kaki. Senam kaki dapat meningkatkan aliran darah dan memperlancar sirkulasi darah, hal ini membuat lebih banyak jala-jala kapiler terbuka sehingga lebih banyak reseptor insulin yang tersedia dan aktif. Hasil penelitian didapatkan terdapat pengaruh senam kaki pada kadar gula darah dan perbedaan pengaruh usia terhadap perubahan rata-rata kadar gula darah antara sebelum dan setelah senam kaki. Untuk kelompok muda pengaruh senam kaki terbukti lebih efektif. Terdapat perbedaan yang signifikan dari intensitas melakukan senam diabetes terhadap perubahan kadar gula darah. Mereka yang lebih lama melakukan senam diabetes mengalami penurunan kadar gula lebih tinggi setelah melakukan senam kaki.

Dalam jurnal Hardika (2018) tentang Pengaruh senam kaki diabetes terhadap penurunan kadar gula darah pada pasien diabetes mellitus tipe II. Jenis penelitian ini menggunakan one group pretest-postest. Subjek penelitian ini adalah penderita diabetes mellitus, dengan rentang usia diantara Usia 4049 tahun sebanyak 10 responden dengan persentase $33.3 \%$, usia 50-59 tahun sebanyak 14 responden dengan persentase $46.7 \%$, usia 60-70 sebanyak 6 responden dengan persentase $20.0 \%$, durasi latihan dilakukan 3-5 kali seminggu. Hasil penelitian didapat nilai ratarata kadar gula darah sebelum melakukan senam kaki $202.67 \mathrm{mg} / \mathrm{dl}$, setelah senam kaki menurun menjadi $173.07 \mathrm{mg} / \mathrm{dl}$. Hasil analisis menunjukkan adanya perbedaan kadar gula darah yang signifikan pada pasien diabetes mellitus tipe II sebelum dan setelah melakukan senam kaki diabetes $(\mathrm{p}<0.01)$.

Dalam penelitian Hardika (2018) dijelaskan bahwa upaya dalam mengendalikan gula darah dapat dilakukan dengan terapi non farmakologi seperti senam kaki. Hal tersebut dikarenakan penderita yang mengalami diabetes melitus disebabkan oleh kerusakan pankreas dalam memproduksi insulin, dimana insulin ini berfungsi dalam mengendalikan kadar gula darah. Penurunan kadar gula darah ini sebagai salah satu indikasi terjadinya perbaikan diabetes mellitus yang dialami. Oleh karena itu pemberian aktivitas senam kaki merupakan salah satu cara yang efektif dalam mengelola diabetes melitus. Senam kaki diabetes melitus merupakan kegiatan atau latihan yang di lakukan oleh penderita diabetes melitus untuk mencegah terjadinya luka dan membantu melancarkan peredaran darah bagian kaki.

Berdasarkan penelitian Nurlinawati (2018) tentang Pengaruh senam kaki diabetes terhadap perubahan kadar gula darah pada penderita diabetes melitus. Rancangan penelitian yang dipergunakan yaitu pre and post test group desing with control group. Subjek penelitian ini adalah penderita diabetes melitus di Wilayah Kerja Puskesmas Simpang Sungai Duren Kab. Muaro Jambi sebanyak 22 
responden, dimana 11 responden diberikan (treatment) senam kaki dan 11 responden responden tidak diberikan senam kaki. Dengan mayoritas usia responden 5-60 tahun sebanyak 57,3\% dan durasi latihan dilakukan 3 kali dalam seminggu. Hasil penelitian diketahui Sebelum dilakukan senam kaki diketahui bahwa seluruh (100\%) responden pada kelompok intervensi dan kontrol mengalami kadar gula darah tinggi. Setelah dilakukan senam kaki diketahui bahwa sebanyak 11 (100\%) responden pada kelompok intervensi mengalami penurunan kadar gula darah. Hasil penelitian diketahui ada pengaruh terhadap penurunan kadar gula darah responden pada kelompok intervensi.

Berdasarkan penelitian Nurlinawati (2018) Olahraga akan meningkatkan pemakaian glukosa oleh otot yang aktif, dimana otot mengubah simpanan glukosa menjadi energi sehingga secara langsung dapat menyebabkan penurunan glukosa dalam darah. Selain itu, pada saat berolahraga atau melakukan latihan fisik terjadi pembakaran kalori yang menambah metabolisme tubuh, sehingga selain dapat mengendalikan kadar gula darah juga dapat menurunkan berat badan sehingga olahraga akan mengurangi jumlah kadar glukosa darah.

Dalam jurnal Rehmaita (2017) tentang Pengaruh Senam Diabetes Dan Jalan Kaki Terhadap Penurunan Kadar Gula Darah Pada Pasien Dm Tipe II Di Puskesmas Krueng Barona Jaya Aceh Besar. Jenis penelitian ini menggunakan one group pretest-postest. Subjek penelitian ini adalah penderita diabetes mellitus, dengan rentang usia diantara Usia < 50 tahun sebanyak $33.3 \%$, dan usia $\geq 50$ tahun sebanyak $66,7 \%$, durasi latihan dilakukan 1 kali seminggu. Hasil penelitian didapat adanya pengaruh yang signifikan terhadap penurungan kadar gula darah (KGD) pada pasien diabetes mellitus type II akibat kegiatan senam diabetes $(\mathrm{p}$-value $=0.002)$ dan jalan kaki (p-value $=$ 0.001). Kegiatan aktifitas fisik, baik senam diabetes maupun jalan kaki, sangat baik dilakukan oleh penderita diabetes melitus tipe II untuk menurunkan kadar gula darah. Kegiatan olahraga apabila dilaksanakan secara baik, benar, teratur dan terukur akan membantu menstabilkan kadar gula darah (KGD), membantu mengurangi kebutuhan insulin atau obat-obatan serta memelihara berat badan.
Dalam jurnal Rehmaita (2017) dijelaskan bahwa kegiatan aktifitas fisik, baik senam diabetes maupun jalan kaki, sangat baik dilakukan oleh penderita diabetes melitus tipe II untuk menurunkan kadar gula darah. Kegiatan olahraga apabila dilaksanakan secara baik, benar, teratur dan terukur akan membantu menstabilkan kadar gula darah (KGD), membantu mengurangi kebutuhan insulin. Latihan jasmani merupakan upaya awal dalam mencegah, mengontrol, serta mengatasi meningkatnya kadar glukoksa dalam darah. Salah satu latihan jasmani yang dianjurkan adalah senam DM. Persatuan Diabetes Indonesia (PERSADIA).

Latihan jasmani yang berupa olah raga dapat menyebabkan terjadinya peningkatan aliran darah, pembuluh kapiler lebih banyak terbuka sehingga lebih banyak tersedia reseptor insulin dan reseptor menjadi akan lebih aktif yang akan berdampak terhadap penurunan glukosa darah pada pasien diabetes. Senam diabetes mellitus tipe 2 berperan dalam pengaturan kadar glukosa darah karena glukosa otot yang sedang bekerja dapat mencapai kenaikan sampai 15-20 kali lipat akibat peningkatan laju metabolic pada otot yang aktif dan hal ini dapat memperbaiki profil lemak, meningkatkan sensitivitas insulin sehingga akan menurunkan glukosa darah. Selain bermanfaat dalam mengontrol kadar glukosa darah, senam pada diabetes mellitus tipe 2 juga dapat menurunkan berat badan (Rehmaita, 2017).

Dalam jurnal Nasution (2017) tentang Pengaruh senam kaki dalam meningkatkan sirkulasi darah kaki pada pasien diabetes melitus sebelum dan sesudah di berikan perlakuan senam kaki di RSUP Haji Adam Malik Medan. Jenis penelitian ini menggunakan one group pretest-postest. Subjek penelitian ini adalah penderita diabetes mellitus, dengan rentang usia diantara Usia < 50 tahun sebanyak 4 orang, dan usia $\geq 50$ tahun sebanyak 6 orang, durasi latihan dilakukan 3 kali seminggu. Hasil penelitian didapat bahwa sirkulasi darah kaki setelah melakukan senam kaki meningkat secara signifikan dengan $p=$ 0,002 berarti $p<0,05$. Sedangkan pada kelompok kontrol $p=0,903(p>0,05)$. Sehingga praktek senam kaki berpengaruh memperbaiki keadaan kaki, dimana akral yang 
dingin meningkat menjadi lebih hangat, kaki yang kaku menjadi lentur, kaki kebas menjadi tidak kebas, dan kaki yang atrofi perlahanlahan kembali normal. Dari uji statistik didapat bahwa senam kaki dapat membantu memperbaiki otot-otot kecil kaki pada pasien diabetes dengan neuropati. Selain itu dapat memperkuat otot betis dan otot paha, mengatasi keterbatasan gerak sendi dan mencegah terjadinya deformitas

Dalam jurnal Nasution (2017) dijelaskan bahwa praktek senam kaki berpengaruh memperbaiki keadaan kaki, dimana akral yang dingin meningkat menjadi lebih hangat, kaki yang kaku menjadi lentur, kaki kebas menjadi tidak kebas, dan kaki yang atrofi perlahan-lahan kembali normal. Dari uji statistik didapat bahwa senam kaki dapat membantu memperbaiki otot-otot kecil kaki pada pasien diabetes dengan neuropati. Selain itu dapat memperkuat otot betis dan otot paha, mengatasi keterbatasan gerak sendi dan mencegah terjadinya deformitas. Keterbatasan jumlah insulin pada penderita DM mengakibatkan kadar gula dalam darah meningkat hal ini menyebabkan rusaknya pembuluh darah, saraf, dan struktur internal lainnya sehingga pasokan darah ke kaki semakin terhambat, akibatnya pasien DM akan mengalami gangguan sirkulasi darah pada kakinya.

Dalam jurnal Endriyanto (2016), tentang Efektivitas Senam Kaki Diabetes Melitus Dengan Koran Terhadap Tingkat Sensitivitas Kaki Pada Pasien DM Tipe 2 Di Instalasi Rawat Inap RSUD Arifin Achmad Pekanbaru. Jenis penelitian ini menggunakan one group pretest-postest. Subjek penelitian ini adalah penderita diabetes mellitus, dengan rentang usia diantara umur responden mayoritas adalah 46-50 tahun (46.7\%), durasi latihan dilakukan 3-4 kali seminggu. Hasil penelitian didapat nilai rata-rata sensitivitas kaki pada kelompok eksperimen sebelum lakukan senam kaki DM dengan koran sebesar 4,35 dan pada kelompok kontrol sebesar 3,56. Setelah diberikan perlakuan dengan melakukan senam kaki DM dengan koran selama 7 hari berturut-turut, pada kelompok eksperimen terjadi peningkatan rata-rata sensitivitas sebesar 4,85 , sedangkan pada kelompok kontrol yang tidak diberikan perlakuan tetap yaitu sebesar
3,56. Hasil penelitian ini menunjukkan adanya peningkatan sensitivitas kaki yang signifikan pada kelompok eksperimen setelah diberikan perlakuan dengan hasil uji statistik $p<0.05$. Dapat disimpulkan bahwa melakukan senam kaki diabetes melitus dengan koran dapat meningkatkan sensitivitas kaki pada pasien DM tipe 2.

Dalam jurnal Endriyanto (2016), menjelaskan bahwa gerakan senam kaki diabetes ini sangatlah mudah untuk dilakukan (dapat di dalam atau di luar ruangan). Senam kaki dapat membantu memperbaiki otot-otot kecil kaki pada pasien diabetes dengan neuropati. Selain itu dapat memperkuat otot betis dan otot paha, mengatasi keterbatasan gerak sendi dan mencegah terjadinya deformitas. Keterbatasan jumlah insulin pada penderita DM mengakibatkan kadar gula dalam darah meningkat hal ini menyebabkan rusaknya pembuluh darah, saraf, dan struktur internal lainnya sehingga pasokan darah ke kaki semakin terhambat, akibatnya pasien DM akan mengalami gangguan sirkulasi darah pada kakinya.

Dalam jurnal Ruben (2016), tentang pengaruh senam kaki diabetes terhadap perubahan kadar gula darah pasien diabetes melitus tipe 2 diwilayah kerja puskesmas Enemawira. Jenis penelitian ini menggunakan one group pretest-postest. Subjek penelitian ini adalah penderita diabetes mellitus, dengan rentang usia diantara umur responden mayoritas responden paling banyak umur 51-60 tahun dengan jumlah 34 responden $(60,7 \%)$, umur 40-50 tahun sebanyak 21 responden (37,5\%), dan umur 61-70 tahun sebanyak 1 responden $(1,8 \%)$. Durasi latihan dilakukan 3-4 kali seminggu. Hasil penelitian didapatkan diketahui bahwa kadar gula darah seluruh responden sebelum melakukan senam kaki adalah $\geq 200 \mathrm{mg} / \mathrm{dl}$. Sesudah melakukan senam kaki $150-199 \mathrm{mg} / \mathrm{dl}$ berjumlah 42 responden $(75 \%)$ dan kadar gula darah $\geq 200 \mathrm{mg} / \mathrm{dl}$ berjumlah 14 responden (25\%). Berdasarkan hasil uji Paired Sample t-test diperoleh nilai $\mathrm{p}=$ 0,00 untuk itu berarti nilai $p=0,00$ lebih kecil dari pada nilai $\alpha=0,05$ maka Ho ditolak yang berarti ada pengaruh senam kaki diabetes terhadap perubahan kadar gula darah pada pasien diabetes melitus tipe 2 di wilayah kerja Puskesmas Enemawira. 
Dalam jurnal Ruben (2016), dijelaskan bahwa pada saat latihan (senam) kebutuhan energi meningkat sehingga otot menjadi lebih aktif dan terjadi peningkatan pemakaian glukosa sehingga terjadi penurunan kadar gula darah, hal ini juga dilatarbelakangi oleh faktor kontinuitas atau keteraturan pasien dalam mengikuti senam sehingga terjadi penurunan kadar gula darah. Olahraga atau latihan fisik merupakan bagian yang tidak dapat dipisahkan dari perawatan penderita diabetes melitus.

Dalam jurnal Flora (2013) tentang Pengaruh senam kaki diabetes terhadap perubahan kadar gula darah pasien diabetes melitus di Puskesmas Indralaya. Jenis penelitian ini menggunakan one group pretestpostest. Subjek penelitian ini adalah penderita diabetes mellitus, dengan rentang usia diantara umur responden < 50 tahun sebanyak 30,5\% dan usia $\geq 50$ tahun sebanyak $60,5 \%$. Durasi latihan dilakukan 3 kali seminggu. Dari kegiatan ini dapat disimpulkan bahwa seluruh peserta (100\%) mengetahui tujuan dilakukannya senam kaki, mengetahui manfaat senam kaki, mengetahui indikasi dan kontraindikasi senam kaki dan antusias, perhatian serta aktif selama kegiatan pelatihan senam kaki. Senam kaki merupakan latihan yang dilakukan bagi penderita Diabetes Melittus (DM) atau bukan penderita untuk mencegah terjadinya luka dan membantu melancarkan peredaran darah bagian kaki. Gerakan-gerakan senam kaki ini dapat memperlancar peredaran darah di kaki, memperbaiki sirkulasi darah, memperkuat otot kaki dan mempermudah gerakansendi kaki. Dengan demikian diharapkan kaki penderita diabetes dapat terawat baik dan dapat meningkatkan kualitas hidup penderita diabetes. Manfaat senam kaki dapat membantu memperbaiki sirkulasi darah dan juga memperkuat otot-otot kecil kaki serta mencegah terjadinya kelainan bentuk kaki. Selain itu, senam kaki juga dapat meningkatkan kekuatan pada otot paha, betis, dan juga mengatasi keterbatasan dalam pergerakan sendi.

Dalam jurnal Flora (2013) dijelaskan bahwa senam kaki merupakan latihan yang dilakukan bagi penderita Diabetes Melittus (DM) atau bukan penderita untuk mencegah terjadinya luka dan membantu melancarkan peredaran darah bagian kaki. Gerakan-gerakan senam kaki ini dapat memperlancar peredaran darah di kaki, memperbaiki sirkulasi darah, memperkuat otot kaki dan mempermudah gerakansendi kaki. Dengan demikian diharapkan kaki penderita diabetes dapat terawat baik dan dapat meningkatkan kualitas hidup penderita diabetes. Manfaat senam kaki dapat membantu memperbaiki sirkulasi darah dan juga memperkuat otot-otot kecil kaki serta mencegah terjadinya kelainan bentuk kaki. Selain itu, senam kaki juga dapat meningkatkan kekuatan pada otot paha, betis, dan juga mengatasi keterbatasan dalam pergerakan sendi. Senam kaki bertujuan untuk memperbaiki sirkulasi darah, memperkuat otototot kecil, mencegah terjadinya kelainan bentuk kaki, meningkatkan kekuatan otot betis dan paha, mengatasi keterbatasan gerak.

Dalam jurnal Sulistyowati (2017), tentang Pengaruh senam kaki terhadap kadar gula darah sewaktu pada penderita diabetes mellitus tipe II di wilayah kerja Puskesmas Cawas 1. Desain penelitian pretest-posttest control group design. Uji statistik menggunakan Paired t-test, Wilcoxon, Independent $t$-test. Sampel pada penelitian ini adalah 32 penderita DM tipe II di wilayah Kerja Puskesmas Cawas 1. Mayoritas usia responden berusia $<50$ tahun sebanyak 4 orang, dan usia $\geq 50$ tahun sebanyak 6 orang, durasi latihan dilakukan 3 kali seminggu. Hasil penelitian didapatkan hasil pengukuran kadar gula darah sewaktu pada responden kelompok eksperimen dan kelompok kontrol di wilayah kerja Puskesmas Cawas 1. Selama 7 hari penelitian diperoleh rata-rata kadar gula darah sewaktu pretest pada kelompok eksperimen adalah 182,38, sedangkan pada posttest adalah 142,94, dan memiliki selisih antara rata-rata posttest dengan pretest sebesar -39,44. Sedangkan pada kelompok kontrol, pengukuran kadar gula darah sewaktu pretest diperoleh rata-rata 177,88 , dan rata-rata posttest adalah 178,81 serta memiliki selisih antara rata-rata posttest dan pretest sebesar 0,94. Ada perbedaan rerata kadar gula darah sewaktu pretest dan posttest pada kelompok eksperimen dengan nilai signifikan 0,000 .

Dalam jurnal Sulistyowati (2017) dijelaskan bahwa latihan jasmani atau olahraga sangat penting dalam penatalaksanaan diabetes 
karena efeknya dapat menurunkan kadar glukosa darah dengan meningkatkan pengambilan glukosa oleh otot dan memperbaiki pemakaian insulin. Latihan jasmani akan menyebabkan terjadinya peningkatan aliran darah, maka akan lebih banyak jala-jala kapiler terbuka sehingga lebih banyak tersedia reseptor insulin dan reseptor menjadi aktif yang akan berpengaruh terhadap penurunan glukosa darah pada pasien diabetes. Latihan jasmani atau olahraga yang dianjurkan salah satunya adalah senam kaki diabetes melitus. Senam kaki bertujuan untuk memperbaiki sirkulasi darah sehingga nutrisi ke jaringan lebih lancar, memperkuat otot-otot kecil, otot betis dan otot paha, menurunkan kadar gula darah serta mengatasi keterbatasan gerak sendi yang dialami oleh penderita diabetes mellitus. Senam kaki diabetes melitus bisa dilakukan dengan posisi berdiri, duduk dan tidur dengan menggerakkan kaki dan sendi misalnya dengan kedua tumit diangkat, mengangkat kaki dan menurunkan kaki.

Dalam jurnal Oktaviah (2015), tentang Sensitivitas kaki terhadap senam kaki diabetik dengan bola plastik pada pasien DM tipe 2 pada kelompok eksperimen dan kelompok kontrol. Desain penelitian yang digunakan Quasi Eksperimen untuk mengungkapkan hubungan sebab akibat dengan cara melibatkan kelompok kontrol disamping kelompok eksperimen. Sampel pada penelitian ini adalah 30 responden, 15 responden kelompok eksperimen dan 15 responden lagi kelompok kontrol yang menderita DM tipe 2 di RSUD Arifin Achmad Pekanbaru. Usia responden mayoritas 45-55 tahun sebesar $55,5 \%$ dengan durasi pelaksanaan senam kaki dilakukan sebanyak 3 kali dalam seminggu. Hasil penelitian ini menunjukkan adanya peningkatan sensitivitas kaki yang signifikan pada kelompok eksperimen setelah diberikan perlakuan dengan hasil uji statistik $p<0,05$. Hasil penelitian ini dapat disimpulkan bahwa melakukan senam kaki diabetik dengan bola plastik selama tiga kali dalam seminggu mampu meningkatkan sensitivitas kaki pada pasien diabetes melitus tipe 2.

Dalam jurnal Oktaviah (2015), dijelaskan bahwa senam kaki diabetik dengan bola plastik mampu meningkatkan sensitivitas kaki. Dimana senam kaki tersebut membuat rileks dan melancarkan peredaran darah. Lancarnya peredaran darah karena dipijat, memungkinkan darah mengantar lebih banyak oksigen dan gizi ke sel-sel tubuh, sekaligus membawa lebih banyak racun untuk dikeluarkan. Pijat refleksi seperti senam kaki diabetik yang dilakukan pada telapak kaki terutama di area organ yang bermasalah, akan memberikan rangsangan pada titik-titik saraf yang berhubungan dengan pankreas agar menjadi aktif sehingga menghasilkan insulin melalui titik-titik saraf yang berada di telapak kaki dan hal tersebut akan mencegah terjadinya komplikasi pada kaki. Oleh karena itu, melakukan senam kaki diabetik dengan bola plastiki efektif terhadap peningkatan sensitivitas kaki pada pasien DM Tipe 2.

Dalam penelitian Wulandari (2018) tentang Pengaruh Pendidikan Kesehatan Senam Kaki Melalui Media Audio Visual Terhadap Pengetahuan Pelaksanaan Senam Kaki Pada Pasien Dm Tipe 2. Desain penelitian Quasi Eksperimen pretest dan post test. Sampel berjumlah 30 pasien diabetes mellitus. mayoritas responden berumur 45-60 tahun (dewasa akhir) yaitu 16 orang $(53,3 \%)$, dan durasi latihan senam kaki dilakukan 2-3 kali dalam seminggu. Setelah dilakukan penelitian, maka dapat disimpulkan pemberian pendidikan kesehatan melalui media audio visual pada kelompok eksperimen meningkatkan pengetahuan pelaksanaan senam kaki pada pasien DM tipe 2. Berdasarkan hasil uji wilcoxon, diperoleh $p$ value $(0,002)<\alpha(0,05)$. Setelah dilakukan penelitian, maka dapat disimpulkan pemberian pendidikan kesehatan melalui media audio visual pada kelompok eksperimen meningkatkan pengetahuan pelaksanaan senam kaki pada pasien DM tipe 2 . Berdasarkan hasil uji wilcoxon, diperoleh $\mathrm{p}$ value $(0,002)<\alpha(0,05)$,

Dalam penelitian Wulandari (2018) dijelaskan bahwa melakukan aktivitas olahraga dengan baik hal tersebut menunjukkan diperlukan adanya melakukan olahraga khususnya senam kaki diabetes mellitus.

$$
\text { Dalam penelitian Wahyuni (2019) }
$$

tentang Senam Kaki Diabetik Efektif Meningkatkan Ankle Brachial Index Pasien Diabetes Melitus Tipe 2. Desain yang digunakan adalah Quasi eksperimen dengan pendekatan one-group pre-test - post-test. 
Sampel diambil menggunakan teknik purposive sampling sebanyak 10 orang sampel yang memenuhi kriteria yaitu pasien DM tipe 2 tanpa penyakit penyerta. Mayoritas usia responden antara 40-60 tahun sebesar 85,5\%), durasi senam dilakukan 2-3 kali dalam seminggu. Hasil analisis statistik menunjukkan ada perbedaannilai ABI yang signifikan antara sebelum dan setelah dilakukan senam kaki diabetik ( $\mathrm{p}$ value $=0,005)$. Disimpulkan bahwa pelaksanaan senam kaki diabetikdapat meningkatkanABI pada pasien DM tipe 2. Dalam penelitian Wahyuni (2019) dijelaskan senam kaki diabettik merupakan cara yang tepat untuk melancarkan sirkulasi terutama ke daerah kaki.Senam kaki merupakan salah satu senam aerobic yang variasi gerakangerakannya pada daerah kaki memenuhi kriteria continous, rhythmical, interval, progresif dan endurance sehingga setiap tahapan gerakan harus dilakukan. Senam yang dianjurkan pada pasien DM yang bersifat aerobik artinya membutuhkan oksigen dan dapat membantu sirkulasi darah, memperkuat otot-otot kecil kaki, mencegah terjadinya kelainan bentuk kaki yang dapat meningkatkan potensi luka diabetik di kaki, meningkatkan produksi insulin yang dipakai dalam transport glukosa ke sel sehingga membantu menurunkan glukosa dalam darah. Gerakan-gerakan kaki yang dilakukan selama senam kaki diabetik sama halnya dengan pijat kaki yaitu memberikan tekanan dan gerakan pada kaki mempengaruhi hormon yaitu meningkatkan sekresi endorphin yang berfungsi sebagai menurunkan sakit, vasodilatasi pembuluh darah sehingga terjadi penurunan tekanan darah terutama sistolik brachialis yang berhubungan langsung dengan nilai ABI.

Dari hasil literatur review terhadap jurnal-jurnal yang telah dibahas diatas dapat disimpulkan bahwa terapi senam kaki sangat efektif dalam menurunkan kadar gula darah penderita diabetes mellitus. Hal ini sesuai dengan teori Akhtyo (2014), yang menyatakan bahwa tujuan senam kaki diabetes mellitus antara lain : Memperbaiki sirkulasi darah, memperkuat otot-otot kecil, mencegah terjadinya kelainan bentuk kaki, meningkatkan kekuatan otot betis dan paha, mengatasi keterbatasan gerak sendi.
Dalam jurnal Denise H. Iunes (2018) yang berjudul Self-Care Associated with Home Exercises in Patients with Type 2 Diabetes Mellitus. Desain penelitian yang digunakan Quasi Eksperimen. Sampel dalam penelitian ini berjumlah 97 pasien diabetes mellitus. Mayoritas usia responden antara $<50$ tahun sebesar 50,5\%), durasi senam dilakukan 2 kali dalam seminggu. Hasil penelitian didapatkan latihan perawatan diri mengubah penyelarasan kaki depan (Kaki Kanan - Awal vs Akhir, p50.04; Kaki Kiri, P, 0,01), pusat perpindahan gaya in mediolateral (Kaki Kanan - Awal versus Final, p50.02; Kaki Kiri, P, 0.01), dan arah anterior-posterior (Kaki kanan - Awal versus Final, p50.01), dan badan keseimbangan (Awal versus Akhir, p50.02). Tidak ada perubahan yang tersisa parameter yang dinilai.

Dalam jurnal Denise H. Iunes (2018) dijelaskan bahwa gerakan kaki yang diberikan dengan metode active lower ROM efektif meningkatkan nilai ABI pada pasien DM karena diyakini bahwa active lower ROM dimulai dari adanya kontraksi otot yang mempengaruhi kerja jantung, vasodilatasi, dan terjadi vasokonstriksi pada pembuluh vena sehingga meningkatkan aliran balik vena. Dalam gerakan senam kaki juga terdapat peregangan kaki (stretching). Stretching kaki dianggap efektif melancarkan sirkulasi darah ke daerah kaki, meningkatkan kerja insulin dan melebarkan pembuluh darah.

Dalam jurnal Jane S. S. P. Ferreira (2020). Tentang Rehabilitation technology for self-care: Customised foot and ankle exercise software for people with diabetes. Desain penelitian yang digunakan Quasi Eksperimen. Sampel dalam penelitian ini berjumlah 29 responden diabetes mellitus. Mayoritas usia responden antara 40-50 tahun sebesar 45,5\%, durasi senam dilakukan 3 kali dalam seminggu. Hasil penelitian didapatkan Di antara spesialis, CVI adalah 0,812 setelah putaran pertama, dan persetujuan akhir adalah $100 \%$ setelah ronde kedua. Di antara pengguna, CVI adalah 0,902 di babak pertama, dan final persetujuan adalah $97 \%$.

Dalam jurnal Jane S. S. P. Ferreira (2020). Dijelaskan bahwa rangsangan yang diberikan dari senam kaki yang baik akan membuat rileks dan melancarkan peredaran darah. Lancarnya peredaran darah karena 
senam kaki, memungkinkan darah mengantar lebih banyak oksigen dan gizi ke sel-sel tubuh, sekaligus membawa lebih banyak racun untuk dikeluarkan. Senam kaki yang dilakukan pada telapak kaki terutama di area organ yang bermasalah, akan memberikan rangsangan pada titik-titik saraf yang berhubungan dengan pankreas agar menjadi aktif sehingga menghasilkan insulin melalui titik-titik saraf yang berada di telapak kaki.

\section{Analisis Penulis}

Dalam penelitian Lariwu (2017) dijelaskan bahwa komponen latihan jasmani atau olahraga sangat penting dalam penatalaksanaan diabetes karena efeknya dapat menurunkan kadar glukosa darah dengan meningkatkan pengambilan glukosa oleh otot dan memperbaiki pemakaian insulin.

Dalam penelitian Wibisana (2017) dijelaskan bahwa pengelolaan DM dapat dilakukan dengan terapi terapi non farmakologis. Terapi non farmakologis meliputi, latihan olahraga. Latihan jasmani merupakan utama penatalaksanaan diabetes mellitus. Latihan jasmani dapat menurunkan kadar glukosa darah karena latihan jasmani akan meningkatkan pemakaian glukosa oleh otot yang aktif.

Dalam penelitian Hardika (2018) dijelaskan bahwa Senam kaki diabetes melitus merupakan kegiatan atau latihan yang di lakukan oleh penderita diabetes melitus untuk mencegah terjadinya luka dan membantu melancarkan peredaran darah bagian kaki.

Berdasarkan penelitian Nurlinawati (2018) Olahraga akan meningkatkan pemakaian glukosa oleh otot yang aktif, dimana otot mengubah simpanan glukosa menjadi energi sehingga secara langsung dapat menyebabkan penurunan glukosa dalam darah

Dalam jurnal Rehmaita

dijelaskan bahwa kegiatan aktifitas fisik, baik senam diabetes maupun jalan kaki, sangat baik dilakukan oleh penderita diabetes melitus tipe II untuk menurunkan kadar gula darah.

Dalam jurnal Nasution (2017) dijelaskan bahwa praktek senam kaki berpengaruh memperbaiki keadaan kaki, dimana akral yang dingin meningkat menjadi lebih hangat, kaki yang kaku menjadi lentur, kaki kebas menjadi tidak kebas, dan kaki yang atrofi perlahan-lahan kembali normal.

Dalam jurnal Endriyanto (2016), menjelaskan bahwa gerakan senam kaki diabetes ini sangatlah mudah untuk dilakukan (dapat di dalam atau di luar ruangan). Senam kaki dapat membantu memperbaiki otot-otot kecil kaki pada pasien diabetes dengan neuropati

Dalam jurnal Ruben (2016), dijelaskan bahwa pada saat latihan (senam) kebutuhan energi meningkat sehingga otot menjadi lebih aktif dan terjadi peningkatan pemakaian glukosa sehingga terjadi penurunan kadar gula darah, hal ini juga dilatarbelakangi oleh faktor kontinuitas atau keteraturan pasien dalam mengikuti senam sehingga terjadi penurunan kadar gula darah

Dalam jurnal Flora (2013) dijelaskan bahwa senam kaki merupakan latihan yang dilakukan bagi penderita Diabetes Melittus (DM) atau bukan penderita untuk mencegah terjadinya luka dan membantu melancarkan peredaran darah bagian kaki

Dalam jurnal Sulistyowati (2017) dijelaskan bahwa latihan jasmani atau olahraga sangat penting dalam penatalaksanaan diabetes karena efeknya dapat menurunkan kadar glukosa darah dengan meningkatkan pengambilan glukosa oleh otot dan memperbaiki pemakaian insulin.

Dalam jurnal Oktaviah (2015), dijelaskan bahwa senam kaki diabetik dengan bola plastik mampu meningkatkan sensitivitas kaki. Dimana senam kaki tersebut membuat rileks dan melancarkan peredaran darah.

Dalam penelitian Wulandari (2018) dijelaskan bahwa melakukan aktivitas olahraga dengan baik hal tersebut menunjukkan diperlukan adanya melakukan olahraga khususnya senam kaki diabetes mellitus.

Dalam penelitian Wahyuni (2019) dijelaskan Senam yang dianjurkan pada pasien DM yang bersifat aerobik artinya membutuhkan oksigen dan dapat membantu sirkulasi darah, memperkuat otot-otot kecil kaki, mencegah terjadinya kelainan bentuk kaki yang dapat meningkatkan potensi luka diabetik di kaki, meningkatkan produksi insulin yang dipakai dalam transport glukosa ke sel sehingga membantu menurunkan glukosa dalam darah. 


\section{KESIMPULAN DAN SARAN Kesimpulan}

Berdasarkan penelitian studi literatur senam kaki diabetes pada penderita diabetes, dengan menganalisis semua sumber dari jurnal menggunakan metode summarize / meringkas, maka didapatkan kesimpulan bahwa metode summarize / meringkas adalah metode dengan cara meringkas semua sumber teori yang berasal dari jurnal.

Setelah dilakukan peneltian dengan menggunakan metode summarize / meringkas ini dengan cara meringkas dari sumber-sumber yang diteliti dari jurnal didapatkan bahwa Latihan senam kaki diabetes akan menyebabkan terjadinya peningkatan aliran darah, maka akan lebih banyak jala-jala kapiler terbuka sehingga lebih banyak tersedia reseptor insulin dan reseptor menjadi lebih aktif yang akan berpengaruh terhadap penurunan glukosa darah pada pasien diabetes. Latihan jasmani dapat menurunkan kadar glukosa darah karena latihan jasmani akan meningkatkan pemakaian glukosa oleh otot yang aktif. Salah satu dari latihan jasmani adalah senam kaki.

\section{Saran}

\section{Bagi Stikes Mitra Adiguna Palembang}

Diharapkan dapat lebih menfasislitasi (misalnya memperbanyak referensi atau literatur yng berkaitan dengan penelitian) dan memberi kemudahan kepada mahasiswa untuk melakukan penelitian demi perkembangan ilmu pengetahuan serta penelitian ini dapat menjadi konstribusi tambahan berupa informasi, pengetahuan dan pemahaman lebih berupa sumbangan fikiran melalui metode pendidikan sebagai bahan referensi guna pengembangan ilmu pengetahuan khususnya ilmu keperawatan.

\section{Bagi Penelitian Selanjutnya}

Diharapkan hasil penelitian ini sebagai acuan bagi peneliti sendiri dan peneliti selanjutnya agar dapat melanjutkan penelitian berikutnya dengan metode yang berbeda tentang penanganan diabetes mellitus sehingga dapat lebih bervariasi.

\section{DAFTAR PUSTAKA}

Akhtyo. 2014. Senam kaki diabetik. http://www.akhtyo.blogspot.com, diakses 5 Januari 2020

Bustan, Nadjib. 2015. Manajemen pengendalian penyakit tidak menular. Jakarta : Rineka Cipta

Damayanti, Santi. 2016. Diabetes mellitus dan penatalaksanaan keperawatan. Yogyakarta : Nuha Medika

Endriyanto. 2016. Pengaruh senam kaki terhadap peningkatan sirkulasi darah kaki pada pasien diabetes mellitus di RSUD Haji Adam Malik. (Jurnal)

Flora. 2017. Pelatihan Senam Kaki Pada Penderita Diabetes Mellitus Dalam Upaya Pencegahan Komplikasi Diabetes Pada Kaki (Diabetes Foot)

Hardika. 2018. Penurunan Gula Darah Pada Pasien Diabetes Melitus Tipe Ii Melalui Senam Kaki Diabetes

Kemenkes. 2018. Infodatin Diabetes Mellitus. www.kemenkes.go.id, diakses 23 Januari 2020

Nurlinawati. 2018. Pengaruh senam kaki diabetes terhadap perubahan kadar gula darah pada penderita diabetes melitus

Lariwu. 2017. Pengaruh Senam Kaki Diabetes Terhadap Penurunan Kadar Gula Darah Pada Pasien Diabetes Mellitus Tipe Ii Di Klinik Husada Manado

Nasution. 2017. Pengaruh senam kaki terhadap peningkatan sirkulasi darah kaki pada pasien penderita Diabetes Melitus di RSUD Haji Adam Malik. (Jurnal).

Notoatmodjo, Soekidjo. 2018. Metodologi penelitian kesehatan. Jakarta. Rineka Cipta 
Sari, Retno Novita. 2017. Diabetes Mellitus. Yogyakarta : Nuha Medika

Shabella, Rifdah. 2016. Terapi herbal buah sayuran untuk diabetes. Klaten : Cable Book.

Syamsiah. 2017. Pengaruh Senam Diabetes Dan Jalan Kaki Terhadap Penurunan Kadar Gula Darah Pada Pasien Dm Tipe II Di Puskesmas Krueng Barona Jaya Aceh Besar

Rehmaita. 2017. Pengaruh Senam Diabetes Dan Jalan Kaki Terhadap Penurunan Kadar Gula Darah Pada Pasien Dm Tipe II Di Puskesmas Krueng Barona Jaya Aceh Besar

Tandra, Hans. 2017. Segala sesuatu yang harus anda ketahui tentang diabetes. Jakarta : PT. Gramedia

Triwibowo. 2019. Pengaruh Senam Kaki Diabetes Terhadap Perubahan Kadar Gula Darah Pada Penderita Diabetes Melitus Di Wilayah Kerja Puskesmas Simpang Sungai Duren Kabupaten Muaro Jambi

Wahyu. 2017. Analisis Faktor Resiko Penyebab Terjadinya Diabetes Melitus Tipe 2 Pada Wanita Usia Produktif Dipuskesmas Wawonasa

Wibisana. 2017. Pengaruh Senam Kaki Terhadap Kadar Gula Darah Pasien Diabetes Melitus Di Rsu Serang Provinsi Banten Tahun 2017 